\title{
Wellness room as a strategy to reduce occupational stress: quasi-experimental study
}

Sala de bem-estar como estratégia para redução do estresse ocupacional: estudo quase-experimental Sala de bienestar como estrategia para la reducción del estrés ocupacional: estudio cuasi-experimental

João Paulo Belini Jacques', Renata Perfeito Ribeiro", Alessandro Rolim Scholze", Maria José Quina Galdino"I", Júlia Trevisan Martins", Benedita Gonçalves de Assis Ribeiro ${ }^{\text {IV }}$

' Universidade Estadual de Londrina, Residence in Perioperative Nursing. Londrina, Paraná, Brazil.

"Universidade Estadual de Londrina, Postgraduate Program in Nursing. Londrina, Paraná, Brazil.

I'I Universidade Estadual do Norte do Paraná, Connections. Bandeirantes, Paraná, Brazil.

Iv Universidade Estadual de Londrina, Center for Health Sciences, Department of Nursing. Londrina, Paraná, Brazil.

\section{How to cite this article:}

Jacques JPB, Ribeiro RP, Scholze AR, Galdino MJQ, Martins JT, Ribeiro BGA. Wellness room as a strategy to reduce occupational stress: quasi-experimental study. Rev Bras Enferm [Internet]. 2018;71(Suppl 1):483-9. [Thematic Issue: Contributions and challenges of nursing practices in collective health] DOI: http://dx.doi.org/10.1590/0034-7167-2017-0572

\section{ABSTRACT}

Objective: To compare occupational stress levels of nurse staff working in the surgical unit before and after the intervention "wellness room". Method: Quasi-experimental study with a sample of 60 nurse staff working in a surgical unit of a teaching hospital in the Southern Region of Brazil. The intervention was conducted in a room in the workplace for six months and consisted of sections of aesthetic care, relaxation, lectures and workshops to reduce occupational stress. Data were collected through the Demand-ControlSupport Questionnaire before and after the intervention, and the comparative analysis was performed by the Wilcoxon test. Results: After the intervention, there was a decrease in demand and an increase in control and in the social support received at work in all professional categories, but the differences were not statistically significant. Conclusion: The intervention "wellness room" reduced occupational stress levels in the sample studied; however, it was not a significant decrease.

Descriptors: Occupational Health; Nursing; Stress, Psychological; Working Environment; Clinical Trial.

\section{RESUMO}

Objetivo: Comparar os níveis de estresse ocupacional entre trabalhadores de enfermagem do bloco cirúrgico antes e após a intervenção "sala de bem-estar". Método: Estudo quase-experimental com amostra de 60 trabalhadores de enfermagem do bloco cirúrgico de um hospital escola da Região Sul do Brasil. A intervenção foi realizada por seis meses e consistiu em seções de cuidados estéticos, de relaxamento, palestras e oficinas para redução do estresse ocupacional em uma sala no local de trabalho. Os dados foram coletados pelo Demand-Control-Support Questionnaire antes e após a intervenção, sendo a análise comparativa realizada pelo teste de Wilcoxon. Resultados: Após a intervenção, houve diminuição da demanda, aumento do controle e do apoio social recebido no trabalho em todas as classes ocupacionais da enfermagem, mas as diferenças não apresentaram significância estatística. Conclusão: A intervenção "sala de bem-estar" reduziu os níveis de estresse ocupacional na amostra pesquisada, apesar de não se tratar de diminuição significativa.

Descritores: Saúde do Trabalhador; Enfermagem; Estresse Psicológico; Ambiente de Trabalho; Ensaio Clínico.

\section{RESUMEN}

Objetivo: Comparar los niveles de estrés ocupacional entre trabajadores de enfermería de la sección quirúrgica antes y después de la intervención "sala de bienestar". Método: Estudio cuasi-experimental con una muestra de 60 trabajadores de enfermería del bloque quirúrgico de un hospital escuela de la región sur del Brasil. La intervención se realizó durante seis meses y consistió en sesiones de cuidados estéticos, de relajación, con charlas y talleres para la reducción del estrés ocupacional en una sala del lugar de trabajo. Se recolectaron los datos con el Cuestionario Demanda-Control (Demand-Control-Support Questionnaire) antes y después de la intervención, y el análisis comparativo se realizó con la prueba de Wilcoxon. Resultados: Tras la intervención, disminuyó la 
demanda, aumentó el control y el apoyo social recibido en el trabajo, en todas las clases ocupacionales de la enfermería, aunque las diferencias no presentaron significancia estadística. Conclusión: la intervención "sala de bienestar" redujo los niveles de estrés ocupacional en la muestra estudiada a pesar de no haberse observado una disminución significativa.

Descriptores: Salud del Trabajador; Enfermería; Estrés Psicológico; Ambiente de Trabajo; Ensayo Clínico.

CORRESPONDING AUTHOR Maria José Quina Galdino E-mail: mariagaldino@uenp.edu.br

\section{INTRODUCTION}

Occupational stress is a common phenomenon among nursing workers and it is widely reported in the literature, especially among those who work in more complex care settings, such as the surgical unit ${ }^{(1-2)}$. In this sector, the professionals must provide direct and indirect care to patients and families during the perioperative period. Also, they must master therapeutic and technological devices and are exposed to biological, chemical and physical risks ${ }^{(3-4)}$.

Studies carried out in Brazil and abroad demonstrated that stress in this population is multifactorial. However, organizational aspects related to the scope of practice and to the work context are predominant, such as: inflexible hierarchical structure, mainly regarding shifts and rules; incivility and interpersonal problems with members of the multiprofessional team; lack of human and material resources; overload of work and responsibilities; ambiguous and conflicting roles; severity of the patients; and daily contact with suffering and death ${ }^{(1,5-6)}$.

Thus, occupational stress is understood as the conjunction of high demands (high psychological demands related to work rhythm and intensity), lack of control over the work process (insufficient skills and low autonomy) and low social support from managers and peers (low interpersonal interaction and uncooperative environment). This condition, also called "isostrain", may lead to distress and sickness in biopsychosocial functioning ${ }^{(7-8)}$.

Research has shown that occupational stress can have undesirable consequences for the health of these workers, for the organization and for the quality of the nursing care, such as psychosomatic illnesses, cardiovascular problems, depression, burnout syndrome, work accidents, absenteeism, presenteeism, high turnover and adverse events ${ }^{(9-15)}$.

Therefore, it is imperative to develop primary, secondary and tertiary prevention actions to reduce occupational stress and, consequently, reduce the negative repercussions for the health problems of nursing workers. The most effective interventions for prevention and control of occupational stress combine primary prevention to reduce workplace stressors and secondary prevention to improve workers' stress management skills ${ }^{(16-17)}$.

Addressing mental health in the workplace involves knowledge and skills that help prevent occupational stress. Some isolated interventions were considered effective for reducing occupational stress, despite having little scientific evidence, such as mental and physical relaxation techniques, stress management in the organization of work and organizational interventions such as alterations in working conditions, autonomy and interpersonal relations at work. However, there are indications that the combination of these strategies can produce better results in the prevention and control of occupational stress ${ }^{(18-19)}$. In addition, only few studies investigated the effectiveness of these interventions to reduce occupational stress in the surgical unit, despite the fact it is a sector that leads to high levels of occupational stress ${ }^{(20)}$.

\section{OBJECTIVE}

The objective of this study was to compare occupational stress levels of nursing workers in the surgical unit before and after the intervention "wellness room".

\section{METHOD}

\section{Ethical aspects}

The current ethical recommendations for human research were adopted in the development of this study. The project was approved by the Research Ethics Committee of the State University of Londrina.

\section{Design, setting and period}

This is a quasi-experimental study, with pre and postintervention evaluation of a single group. The researchers applied the intervention "wellness room" and observed its effect on the outcome occupational stress.

The study was carried out from January to June 2013 in a teaching hospital in the Southern Region of Brazil, in the surgical unit, which included the surgical center and the material and sterilization center. Approximately 8,100 surgeries occurred every year in this unit, an average of 22 per day, distributed in seven operating rooms that serve 15 surgical specialties.

\section{Population and sample}

The study population consisted of the 75 nurse staff working in the surgical unit of the hospital, of which 49 worked in the surgical center and 26 in the materials and sterilization center. The eligibility criteria for participation in the research were: being a nurse working in this sector for at least two months; participating in at least $75 \%$ of the activities of the intervention proposed in the study; and not being on a leave.

The 75 professionals met these criteria and participated in the pre-intervention evaluation. However, there were 15 losses of professionals who refused to participate in the postintervention evaluation. Thus, the sample of this study was 60 nurses. 


\section{Study Protocol}

Initially, the researchers approached potential research participants in the workplace to present the study and explain its development. All the nurses invited accepted to participate in the intervention and responded to the data collection instrument (pre-intervention/baseline evaluation).

The questionnaire elaborated for data collection included socio-demographic and work-related characteristics with data on age, gender, marital status, years of education, professional category, time of experience in the surgical unit, place of work in the surgical unit, work shift, weekly workload and individual monthly income.

Occupational stress was assessed through the DemandControl-Support Questionnaire, a scale abbreviated by Töres Theorell in 1988 based on the instrument developed by Robert Karasek in $1979^{(8)}$. This questionnaire was adapted and validated for Portuguese by Alves et al. (2004) ${ }^{(21)}$, and it presented good internal consistency (Cronbach's alpha between 0.63 and 0.86 ) and stability (intra-class correlation coefficient between 0.82 and 0.91 ). It is a self-report instrument composed of 17 items on a 4-point Likert-type scale measuring three dimensions: demand (five items), control (six items) and social support (six items).

For six months, research participants were enrolled in a program aimed at reducing and controlling occupational stress, called "wellness room". The intervention was performed in a room prepared for this purpose in the workplace, with the following activities:

- Physical activity at the workplace: performed daily exercises for 15 minutes in the three work shifts (morning, afternoon and night); taught by a fourth-year physical education undergraduate student from a local university, who was trained for this activity;

- "Beauty day": performed monthly, with aesthetic care such as makeup, body massage and skin cleansing; on the same day, breakfast was offered with a free moment for conversation and workers' interaction, as well as a movie section with snacks;

- Auricular acupuncture: performed monthly by a professional trained and with experience in the technique;

- Lectures and workshops on stress management and coping: held monthly, lasting two hours; conducted by researchers and professionals invited, with experience in the topic;

The "wellness room" was used for rest when the activities of this study were not occurring.

At the end of the intervention, the nurses answered the data collection instrument again (post-intervention/completion evaluation).

\section{Analysis of results and statistics}

The data obtained were analyzed using the software Statistical Package for the Social Science (SPSS), version 20.0. Numerical variables did not follow normal distribution, as indicated by the Kolmogorov-Smirnov test. Thus, in the descriptive analyzes, the measures of central tendency and dispersion of the numerical variables were presented in medians and interquartile ranges (25th and 75 th percentiles), while categorical variables were presented in frequency and percentage.

The comparison of the occupational stress levels evaluated in the Demand-Control-Support Questionnaire before and after the intervention was performed by the Wilcoxon test according to the professional category. The level of significance was set at $p<0.05$.

\section{RESULTS}

Initially, 75 nurses were included to receive the "wellness room" intervention, of which $80 \%(n=60)$ completed the follow-up (Figure 1).

The characteristics of the nursing workers analyzed in this study are presented in Table 1. There was a predominance of females, working in the day shift and the median time working was 15 years.

No statistically significant differences were found when comparing the scores on the Demand-Control-Support Questionnaire from before and after the "wellness room" intervention according to the professional category. However, there was a decrease in the perception of work demand and an increase in perceived control and social support received at work (Table 2).

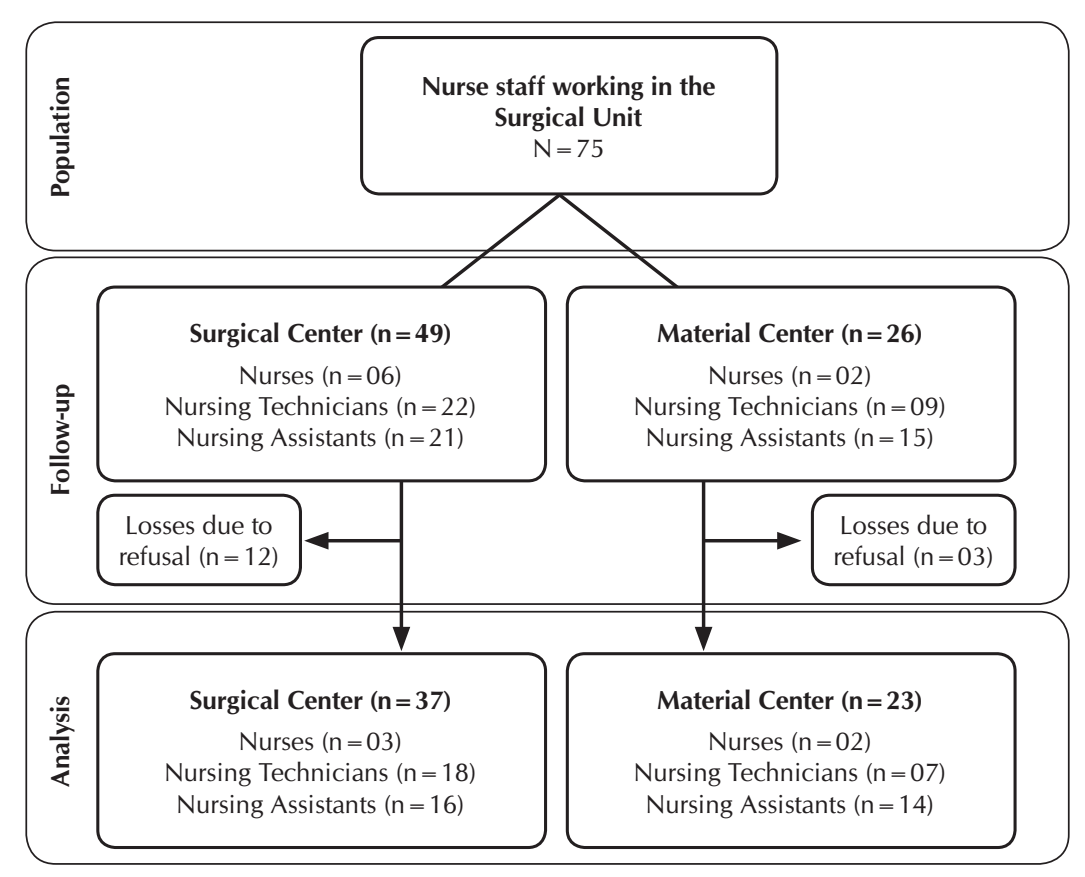

Figure 1 - Flowchart of the sample analyzed, Brazil, 2013 
Table 1 - Socio-demographic and work-related characteristics of nursing workers of the sample analyzed $(n=60)$, Brazil, 2013

\begin{tabular}{|c|c|}
\hline Variables & Frequency (\%) \\
\hline Age & $48.0(43.0-53.0)^{*}$ \\
\hline \multicolumn{2}{|l|}{ Gender } \\
\hline Male & $52(86.7)$ \\
\hline Female & $8(13.3)$ \\
\hline \multicolumn{2}{|l|}{ Civil Status } \\
\hline Single & $29(48.3)$ \\
\hline Married/Common-law marriage & $31(51.7)$ \\
\hline \multicolumn{2}{|l|}{ Years of education } \\
\hline$\leq 9$ years & $36(60.0)$ \\
\hline$\geq 10$ years & $24(40.0)$ \\
\hline \multicolumn{2}{|l|}{ Professional category } \\
\hline Nurse & $5(8.3)$ \\
\hline Nursing technician & $25(41.7)$ \\
\hline Nursing assistant & $30(50.0)$ \\
\hline \multicolumn{2}{|l|}{ Weekly workload } \\
\hline 36 hours & $47(78.3)$ \\
\hline 40 hours & $14(21.7)$ \\
\hline \multicolumn{2}{|l|}{ Workplace } \\
\hline Surgical center & $37(61.7)$ \\
\hline Material and sterilization center & $23(38.3)$ \\
\hline \multicolumn{2}{|l|}{ Work shift } \\
\hline Day & $44(73.3)$ \\
\hline Night & $16(26.7)$ \\
\hline Time working on the surgical unit & $15(6.0-20.0)^{*}$ \\
\hline \multicolumn{2}{|l|}{ Individual monthly income } \\
\hline$\leq \mathrm{R} \$ 2,000.00$ & 18(30.0) \\
\hline $\mathrm{R} \$ 2,001.00$ to $\mathrm{R} \$ 3,000.00$ & $26(43.3)$ \\
\hline $\mathrm{R} \$ 3,001.00$ to $\mathrm{R} \$ 4,000.00$ & $9(15.0)$ \\
\hline$\geq \mathrm{R} \$ 4,000.00$ & $7(11.7)$ \\
\hline
\end{tabular}

Note: *median (interquartile range 25 and 75).

Table 2 - Comparison of the scores on the Demand-Control-Support Questionnaire dimensions before and after the "wellness room" intervention, according to professional category $(n=60)$, Brazil, 2013

\begin{tabular}{lccc}
\hline & Before & After & \multirow{2}{*}{ Professional category } \\
\cline { 2 - 3 } & Median $(\mathbf{I Q R})^{*}$ & Median $(\mathbf{Q Q R})^{*}$ & \\
\cline { 2 - 3 } & Demand & Demand & \\
\hline Nurse $(\mathrm{n}=5)$ & $10.0(9.0-11.0)$ & $7.0(6.0-9.5)$ & 0.074 \\
Nursing technician $(\mathrm{n}=25)$ & $8.0(8.0-10.0)$ & $7.0(7.0-10.0)$ & 0.649 \\
Nursing assistant $(\mathrm{n}=30)$ & $8.0(7.0-9.0)$ & $8.0(7.0-9.0)$ & 0.568 \\
\hline & Control & Control & \\
\hline Nurse $(\mathrm{n}=5)$ & $8.0(7.5-12.5)$ & $8.0(8.0-10.0)$ & 0.285 \\
Nursing technician $(\mathrm{n}=25)$ & $9.0(8.0-11.0)$ & $10.0(9.0-12.5)$ & 0.174 \\
Nursing assistant $(\mathrm{n}=30)$ & $9.5(9.0-11.0)$ & $9.0(8.0-10.0)$ & 0.180 \\
\hline & Social Support & Social Support & \\
\hline Nurse $(\mathrm{n}=5)$ & $11.0(8.0-13.5)$ & $13.0(11.5-16.5)$ & 0.104 \\
Nursing technician $(\mathrm{n}=25)$ & $12.0(10.0-13.5)$ & $13.0(11.0-15.0)$ & 0.143 \\
Nursing assistant $(\mathrm{n}=30)$ & $12.0(10.0-13.0)$ & $13.0(10.0-15.0)$ & 0.354 \\
\hline
\end{tabular}

Note: *median (interquartile range 25 and 75 ); **Wilcoxon test.

\section{DISCUSSION}

In this study, the intervention "wellness room" did not significantly reduce occupational stress levels among the nursing staff of the surgical unit analyzed. However, the participants presented a decrease in the perception of psychological demand and an increase in control and in the social support received at work. These findings contribute to the advancement of knowledge, mainly due to the positive results, and because other studies evaluating the combination of mental health interventions with primary and secondary prevention actions were not found in Brazil, even with the high costs for personnel, social and organizational management associated with occupational stress among nurse staff.

Scientific evidence has shown that, among the preventive interventions, multimodal approaches using more than one technique produce better effects on occupational stress and contribute to the creation of mentally healthy workplaces ${ }^{(22-23)}$. However, there is no recommendation as to how these interventions can be combined and balanced, but only that they can be targeted to a non-specific population (universal prevention), to high risk population (selective prevention) or to those with emerging symptoms (indicated prevention) ${ }^{(24)}$.

Literature indicates several occupational risk factors for mental health issues, including psychological demands, job control, social support, organizational justice, job dissatisfaction, and job insecurity ${ }^{(25-26)}$. Among these, job control is the object of most of the high-quality intervention studies, which do not aim to modify aspects of work organization. In practice, it is easier to increase workers' resilience than to modify risk factors ${ }^{(27-28)}$.

A systematic review found that interventions targeted at problem solving, coping and ways to identify stressors and minimize their impact on work do not have a consistent impact on occupational stress ${ }^{(22)}$. However, a synthesis of systematic reviews indicated that interventions based on cognitive-behavioral therapies have greater effect in reducing occupational stress when compared to relaxation and meditation ${ }^{(29)}$. From this perspective, the development of defense strategies is important for nursing workers in order to cope with the daily stress of the surgical unit, however it should not be an isolated method.

Musculoskeletal pain was observed in $91.8 \%$ of the nursing staff in the surgical unit of a teaching hospital and it led to absenteeism and had a negative impact on quality of life. Thus, muscle conditioning is important for these professionals in order reduce the risk of muscle and spinal injuries, and it can be obtained through physical activity in the workplace ${ }^{(30-31)}$. In this sense, a quasiexperimental study carried out with workers from a Brazilian higher education institution identified that physical activity at the workplace reduced musculoskeletal pain, but did not significantly reduce occupational stress levels ${ }^{(32)}$, a result similar to the present study. 
The positive effects of physical activity on mental health are well documented; however, the impact of physical activity promoted on the workplace is still controversial. A metaanalysis of 13 interventions and seven observational studies found that the combination of aerobic exercise and relaxation reduced anxiety, but did not reduce occupational stress and absenteeism ${ }^{(33)}$. The main limitation of primary research involving workplace exercise programs is the lack of information about the type, quantity and intensity of activity required to produce significant benefits ${ }^{(27)}$.

Self-care has been neglected by health professionals, especially by the nursing staff, who, due to work overload and multiple roles, have insufficient hours of sleep, rest and leisure, irregular physical activity and inadequate nutrition. In addition, they consider that some self-care practices, such as meditation, massage, acupuncture and aesthetic care (skin, nails and hair), are unnecessary in their routine. The sum of these factors can lead to stress and physical, psychological and social issues ${ }^{(34-35)}$.

A randomized controlled trial with 93 female health professionals, mostly nursing workers, from a Brazilian hospital found that different levels of massage (monosensory, bisensory and multisensory) significantly reduced stress and cortisol levels and increased self-esteem of the participants in relation to the control group, which did not receive the intervention ${ }^{(35)}$. These results diverged from those obtained in the present investigation, since massage, associated with other strategies, did not produce a statistically significant reduction on occupational stress.

The use of alternative and complementary therapies for relaxation and stress management - aromatherapy, massage, meditation, music therapy and auriculotherapy - in wellness programs in nurses' workplace has been widely assessed and presented satisfactory results ${ }^{(36)}$. Despite these promising results, relaxation interventions for reducing stress still present evidence of low to moderate quality, since several studies indicate that there are no significant differences between massage for physical and mental relaxation and meditation techniques, such as mindfulness ${ }^{(18)}$.

A study conducted in hospital units in Arizona (United States) showed that aromatherapy, more specifically the diffusion of therapeutic lavender essential oil in the nursing work environment in complex care sectors, decreased work-related stress and increased satisfaction, since good olfactory experiences can promote well-being ${ }^{(37)}$.

Regarding auricular acupuncture, the literature indicates that it reduces not only stress levels, but also anxiety and pain, increasing coping strategies and improving the quality of mental life of the nursing team ${ }^{(38-39)}$.

Regarding the lectures and workshops on stress management and coping, a study assessed Norwegian physicians who received interventions based on an integrative approach incorporating psychodynamic, cognitive and educational theories, with daily lectures, group discussions, and physical activity. These interventions did not produce significant changes in the levels of emotional exhaustion, job stress, emotion-focused coping and neuroticism; however, these levels were significantly higher in comparison to the control group ${ }^{(40)}$.

In general, health promotion programs in the work environment present low and moderate evidence for improved mental health and well-being and decreased absenteeism. Thus, authors conclude that, although such interventions have the potential to prevent mental health problems, additional research is needed to determine the effectiveness of this approach and to identify which components of the intervention produce the most beneficial outcomes ${ }^{(41-42)}$.

Another study identified the need for an adequate and prepared physical space for nursing professionals to rest. A rest space is essential to deal with work overload and lack of human resources, as it can provide relief to the workers' fatigued muscles and to their mental health ${ }^{(34)}$.

There is a considerable body of knowledge and significant advances, but it is clear that effective interventions for the reduction and control of occupational stress are difficult and complex, since they must consider subjectivity, different work contexts and the different stressors to which the workers are subjected. In addition, both the individual and the organization are extremely dynamic, which makes it difficult to control the variables.

\section{Limitations of the study}

The convenience sampling can be cited as a limitation of the present study, since the participants were in only one group and in a single hospital, which prevents the generalization of the results. Also, $20 \%$ of the participants who received the intervention refused to answer the last evaluation, which may also affect the analysis. Another limitation of this investigation was the evaluations carried only at the baseline and at the conclusion of the intervention, with no long-term followup. Thus, future studies should include time series evaluations and follow-up the participants in order to verify the long-term effects of the intervention. Also, future studies should investigate, in addition to self-report measures, the biological parameters of the stress reaction, such as cortisol, in order to confirm the effect of the intervention on occupational stress.

\section{Contributions to the nursing area}

The results of the study indicate the viability of developing and using a "wellness room" in the workplace, with actions that promote self-care, improve social support among the team, increase physical activity, offer physical and mental relaxation, and provide educational practices about stress management and coping, all aiming for reducing stress among nurse staff in the surgical unit. The fact that it did not produce statistically positive effects is important for the scientific evidence produced by systematic reviews with meta-analysis, since it reduces the positivity bias of the studies that use this design. This study represents an advance in knowledge when it demonstrates that wellness actions offered by the institution reduce demand and increase control and social support for nursing staff.

\section{CONCLUSION}

The intervention "wellness room" reduced the perception of demand and increased control over the work process and the social support received in the work and, thus, reduced the levels of occupational stress among nursing workers of the surgical unit studied. However, this decrease was not statistically significant. 


\section{REFERENCES}

1. Zhou H, Gong $\mathrm{YH}$. Relationship between occupational stress and coping strategy among operating theatre nurses in China: a questionnaire survey. J Nurs Manag [Internet]. 2015[cited 2017 Jul 20];23(1):96-106. Available from: http://dx.doi.org/10.1111/ jonm.12094

2. Eskola S, Roos M, McCormack B, Slater P, Hahtela N, Suominen T. Workplace culture among operating room nurses. J Nurs Manag [Internet]. 2016[cited 2017 Jul 20];24(6):725-34. Available from: http://dx.doi.org/10.1111/jonm.12376

3. Silva ROC, Batista KM, Grazziano ES. Hardy personality in medical and nursing staffs in the operating room. Rev SOBECC [Internet]. 2014[cited 2017 Jul 20];19(4):214-8. Available from: http://dx.doi.org/10.5327/Z1414-4425201400040007

4. Sørensen EE, Olsen $\varnothing$, Tewes M, Uhrenfeldt L. Perioperative nursing in public university hospitals: an ethnography. BMC Nursing [Internet]. 2014[cited 2017 Jul 20];13:45. Available from: http://dx.doi.org/10.1186/s12912-014-0045-7

5. Stumm EMF, Botega D, Kirchner RM, Silva LAA. Estressors and symptoms of stress lived by health workers in a surgical center. Rev Min Enferm [Internet]. 2008[cited 2017 Jul 20];12(1):54-66. Available from: http://www.dx.doi.org/S1415-27622008000100008

6. Lenthall S, Wakerman J, Dollard MF, Dunn S, Knight S, Opie T, et al. Reducing occupational stress among registered nurses in very remote Australia: a participatory action research approach. Collegian [Internet]. 2017[cited 2017 Jul 20]. [in press]. Available from: https://doi.org/10.1016/j.colegn.2017.04.007

7. Karasek RA. Job demands, job decision latitude, and mental strain: implications for job redesign. Adm Sci Q [Internet]. 1979[cited 2017 Jul 20];24(2):285-308. Available from: http://www.jstor.org/stable/2392498

8. Karasek RA, Theörell T. Healthy work: stress, productivity, and the reconstruction of working life. New York: Basic Books, 1990.398 p.

9. Niedhammer I, Sultan-Taïeb H, Chastang JF, Vermeylen G, Parent-Thirion A. Fractions of cardiovascular diseases and mental disorders attributable to psychosocial work factors in 31 countries in Europe. Int Arch Occup Environ Health [Internet]. 2014[cited 2017 Jul 20];87(4):403-11. Available from: http://dx.doi.org/10.1007/s00420-013-0879-4

10. Organização Internacional do Trabalho (OIT). A prevenção das doenças ocupacionais. Lisboa: OIT, 2013.17 p

11. Wong CA, Spence Laschinger HK. The influence of frontline manager job strain on burnout, commitment and turnover intention: a cross-sectional study. Int J Nurs Stud [Internet]. 2015[cited 2017 Jul 20];52(12):1824-33. Available from: http://dx.doi. org/10.1016/j.ijnurstu.2015.09.006

12. McTernan WP, Dollard MF, LaMontagne AD. Depression in the workplace: an economic cost analysis of depression-related productivity loss attributable to job strain and bullying. Work Stress [Internet]. 2013[cited 2017 Jul 20];27(4):321-38. Available from: http://dx.doi.org/10.1080/02678373.2013.846948

13. Ferri P, Guadi M, Marcheselli L, Balduzzi S, Magnani D, Di Lorenzo R. The impact of shift work on the psychological and physical health of nurses in a general hospital: a comparison between rotating night shifts and day shifts. Risk Manag Health Policy [Internet]. 2016[cited 2017 Jul 20];14(9):203-11. Available from: http://dx. doi.org/10.2147/RMHP.S115326

14. Enns V, Currie S, Wang J. Professional autonomy and work setting as contributing factors to depression and absenteeism in Canadian Nurses. Nurs Outlook [Internet]. 2015[cited 2017 Jul 20];63(3):269-77. Available from: http://dx. doi.org/10.1016/j. outlook.2014.12.014

15. Yim HY, Seo HJ, Cho Y, Kim JH. Mediating role of psychological capital in relationship between occupational stress and turnover intention among nurses at veterans administration hospitals in Korea. Asian Nurs Res[Internet]. 2017[cited 2017 Jul 20];11(1):612. Available from: http://dx.doi.org/10.1016/j.anr.2017.01.002

16. LaMontagne AD, Keegel T, Louie AM, Ostry A, Landsbergis PA. A systematic review of the job-stress intervention evaluation literature, 1990-2005. Int J Occup Environ Health [Internet]. 2007[cited 2017 Jul 20];13(3):268-80. Available from: http://dx.doi. org/10.1179/oeh.2007.13.3.268

17. West CP, Dyrbye LN, Erwin PJ, Shanafelt TD. Interventions to prevent and reduce physician burnout: a systematic review and meta-analysis. Lancet [Internet]. 2016[cited 2017 Jul 20];388(10057):2272-81. Available from: http://dx.doi.org/10.1016/ S0140-6736(16)31279-X

18. Ruotsalainen JH, Verbeek JH, Mariné A, Serra C. Preventing occupational stress in healthcare workers. Cochrane Database Syst Rev [Internet]. 2015[cited 2017 Jul 20];7(4):152. Available from: http://dx.doi.org/10.1002/14651858.CD002892.pub5

19. LaMontagne AD, Martin A, Page KM, Reavley NJ, Noblet AJ, Milner AJ, et al. Workplace mental health: developing an integrated intervention approach. BMC Psychiatry [Internet]. 2014[cited 2017 Jul 20];14:131. Available from: http://dx.doi. org/10.1186/1471-244X-14-131

20. Brandão DEC, Galvão CM. Nursing team stress in the perioperative period: an integrative review. Rev Rene [Internet]. 2013[cited 2017 Jul 20];14(4):836-44. Available from: http://www.revistarene.ufc.br/revista/index.php/revista/article/viewFile/1115/pdf

21. Alves MGM, Chor D, Faerstein E, Lopes CS, Werneck GL. Short version of the "job stress scale": a Portuguese-language adaptation. Rev Saúde Pública [Internet]. 2004[cited 2017 Jul 20];38(2):164-71. Available from: http://dx.doi.org/10.1590/ S0034-89102004000200003 
22. Seymour L, Grove B. Workplace interventions for people with common mental health problems [Internet]. British Occupational Health Research Foundation: London, UK; 2005[cited 2017 Jul 20]. Available from: http://www.bohrf.org.uk/downloads/cmh_ rev.pdf

23. Harvey SB, Joyce S, Tan L, Johnson A, Nguyen H, Modini M, et al. Developing a mentally healthy workplace: a review of the literature [Internet]. Black Dog Institute: Sydney; 2014 [cited 2017 Jul 20]. Available from: https://www.headsup.org.au/docs/ default-source/resources/developing-a-mentally-healthy-workplace_final-november-2014.pdf?sfvrsn =8

24. Cuijpers P, Beekman AT, Reynolds CF. Preventing depression: a global priority. JAMA [Internet]. 2012 [cited 2017 Jul 20];307(10):1033-4. Available from: http://dx.doi.org/10.1001/jama.2012.271

25. Ndjaboue R, Brisson C, Vezina M. Organisational justice and mental health: a systematic review of prospective studies. Occup Environ Med [Internet]. 2012[cited 2017 Jul 20];69(10):694-700. Available from: http://dx.doi.org/10.1136/oemed-2011-100595

26. Chamberlain SA, Gruneir A, Hoben M, Squires JE, Cummings GG, Estabrooks CA. Influence of organizational context on nursing home staff burnout: a cross-sectional survey of care aides in Western Canada. Int J Nurs Stud [Internet]. 2017 [cited 2017 Jul 20];71:60-69. Available from: http://dx.doi.org/10.1016/j.ijnurstu.2017.02.024

27. Joyce S, Modini M, Christensen H, Mykletun A, Bryant R, Mitchell PB, et al. Workplace interventions for common mental disorders: a systematic meta-review. Psychol Med [Internet]. 2016[cited 2017 Jul 20];46(4):683-97. Available from: http://dx.doi. org/10.1017/S0033291715002408

28. Tan L, Wang MJ, Modini M, Joyce S, Mykletun A, Christensen H, et al. Preventing the development of depression at work: a systematic review and meta-analysis of universal interventions in the workplace. BMC Med [Internet]. 2014 [cited 2017 Jul 20];12:74. Available from: http://dx.doi.org/10.1186/1741-7015-12-74

29. Bhui KS, Dinos S, Stansfeld SA, White PD. A synthesis of the evidence for managing stress at work: a review of the reviews reporting on anxiety, depression, and absenteeism. J Environ Public Health [Internet]. 2012[cited 2017 Jul 20];2012:515874. Available from: http://dx.doi.org/10.1155/2012/515874

30. Vidor CR, Mahmud MAI, Farias LF, Silva CA, Ferrari JN, Comel JC, et al. Prevalence of musculoskeletal pain among surgical nursing teams. Acta Fisiatr [Internet]. 2014[cited 2017 Jul 20];21(1):6-10. Available from: http://www.actafisia trica.org.br/detalhe_ artigo.asp?id $=529$

31. Santana LL, Sarquis LMM, Miranda FMA, Kalinke LP, Felli VEA, Miniel VA. Health indicators of workers of the hospital area. Rev Bras Enferm [Internet]. 2016[cited 2017 Jul 20];69(1):23-32. Available from: http://dx.doi.org/10.1590/0034-7167.2016690104i

32. Freitas-Swerts FCT, Robazzi MLCC. The effects of compensatory workplace exercises to reduce work-related stress and musculoskeletal pain. Rev Latino Am Enfermagem [Internet]. 2014[cited 2017 Jul 20];22(4):629-36. Available from: http://dx.doi. org/10.1590/0104-1169.3222.2461

33. Brown HE, Gilson ND, Burton NW, Brown WJ (2011). Does physical activity impact on presenteeism and other indicators of workplace well-being? Sports Med [Internet]. 2011[cited 2017 Jul 20];41(3):249-62. Available from: http://dx.doi. org/10.2165/11539180-000000000-00000

34. Regis LF, Porto IS. Basic human needs of nursing professional: situations of (dis)satisfaction at work. Rev Esc Enferm USP [Internet]. 2011[cited 2017 Jul 20];45(2):334-41. Available from: http://dx.doi.org/10.1590/S0080-62342011000200005

35. Leão ER, Dal Fabbro DR, Oliveira RB, Santos IR, Victor ED, Aquarone RL, et al. Stress, self-esteem and well-being among female health professionals: a randomized clinical trial on the impact of a self-care intervention mediated by the senses. PLoS One [Internet]. 2017[cited 2017 Jul 20];12(2). Available from: http://dx.doi.org/10.1371/journal.pone.0172455

36. Wright N, Zakarin M, Blake H. Nurses' views on workplace wellbeing programmes. Br J Nurs [Internet]. 2016 [cited 2017 Jul 20];25(21):1208-12. Available from: https://doi.org/10.12968/bjon.2016.25.21.1208

37. Johnson K, West S, Diana S, Todd J, Haynes B, Bernhardt J, et al. Use of aromatherapy to promote a therapeutic nurse environment. Intensive Crit Care Nurs [Internet]. 2017[cited 2017 Jul 20];40:18-25. Available from: https://doi.org/10.1016/j.iccn.2017.01.006

38. Kurebayashi LFS, Turrini RNT, Souza TPB, Marques CF, Rodrigues RTF, Charlesworth K. Auriculotherapy to reduce anxiety and pain in nursing professionals: a randomized clinical trial. Rev Latino-Am Enfermagem [Internet]. 2017 [cited 2017 Jul 25];25. Available from: http://dx.doi.org/10.1590/1518-8345.1761.2843.39.

39. Kurebayashi LFS, Gnatta JR, Borges TP, Belisse G, Coca S, Minami A, et al. The applicability of auriculotherapy with needles or seeds to reduce stress in nursing professionals. Rev Esc Enferm USP [Internet]. 2012 [cited 2017 Jul 25];46(1):89-5. Available from: http://dx.doi.org/10.1590/S0080-62342012000100012

40. Ro KEl, Tyssen R, Hoffart A, Sexton H, Aasland OG, Gude T. A three-year cohort study of the relationships between coping, job stress and burnout after a counselling intervention for help-seeking physicians. BMC Public Health [Internet]. 2010 [cited 2017 Jul 20];10:213. Available from: https://doi.org/10.1186/1471-2458-10-213

41. Kuoppala J, Lamminpaa A, Husman P. Work health promotion, job well-being, and sickness absences - a systematic review and meta-analysis. J Occup Environ Med [Internet]. 2008[cited 2017 Jul 20];50(11):1216-27. Available from: https://doi.org/10.1097/ JOM.0b013e31818dbf92

42. Osilla KC, Van Busum K, Schnyer C, Larkin JW, Eibner C, Mattke S (2012). Systematic review of the impact of worksite wellness. Am J Manag Care [Internet]. 2012[cited 2017 Jul 20];18(2):68-81. Available from: https://www.ncbi.nlm.nih.gov/pubmed/22435887 